\title{
Sexual Differentiation of the Neuroendocrine Mechanisms Regulating Mate Recognition in Mammals
}

\author{
J. Bakker \\ Centre for Cellular and Molecular Neurobiology, Research Group in Behavioural Neuroendocrinology, University of Liege, Liege, Belgium.
}

Key words: oestradiol, sexual differentiation, olfaction, behaviour, aromatase knockout.

\begin{abstract}
When in breeding condition, male and female mammals seek out and mate with opposite-sex conspecifics. The neural mechanisms controlling mate recognition and heterosexual partner preference are sexually differentiated by the perinatal actions of sex steroid hormones. Many mammalian species use odours to identify potential mates. Thus, sex differences in partner preference may actually reflect sex differences in how male and female mammals perceive socially relevant odours. Two olfactory systems have evolved in vertebrates that differ considerably in their anatomy and function. It is generally believed that the main olfactory system is used to detect a wide variety of volatile odours derived from food prey among many sources, whereas the accessory olfactory system has evolved to detect and process primarily nonvolatile odours shown to influence reproductive behaviours and neuroendocrine functions. Some recent results obtained in oestradiol-deficient aromatase knockout (ArKO) mice that provide evidence for a developmental role of oestradiol in olfactory investigation of volatile body odours are discussed, suggesting that: (i) oestrogens contribute to the development of the main olfactory system and (ii) mate recognition is mediated by the main as opposed to the accessory olfactory system. Thus, sex differences in mate recognition and sexual partner preference may reflect sex differences in the perception of odours by the main olfactory system.
\end{abstract}

Importance of odours for mate recognition in mammals

Mate selection or sexual partner preference is highly sexually dimorphic in mammalian species: when in breeding condition, males and females seek out and mate with opposite-sex conspecifics. Accordingly, mating or coital behaviours are also sexually dimorphic in most mammalian species. For example, in rodents, males typically display mounting and intromissive behaviours culminating in ejaculation, whereas females show receptive standing postures such as lordosis in response to the mounting by the male. Many mammalian species use odours to identify potential mates and, accordingly, release to their environment a wide variety of volatile and nonvolatile odours via skin glands and skin microorganisms as well as via excretory products, such as urine and faeces $(1,2)$. These socially relevant odours are also known as pheromones which have been defined as 'substances which are secreted to the outside by an individual and received by a second individual, in which they release a specific reaction such as a behaviour, developmental process or physiological change (e.g. hormone release) to their mutual benefit $(3,4)$. In nocturnal species, such as many rodent species, pheromones may be particularly important to signal the presence of a mate in the dark. As a result, the olfactory acuity of mice and rats allows them to discriminate between the urinary odours of congenic strains that differ only in single genes within the highly polymorphic major histocompatibility complex (MHC), a family of approximately 50 genes best known for their critical role in cell-cell recognition (5, 6). Male mice have been demonstrated to display mating preferences for oestrous females with dissimilar MHC types, suggesting that mice use MHC-determined body odours to avoid inbreeding $(5,7)$. In addition, male house mice also use a class of proteins known as major urinary proteins (MUP) that bind and release small volatile molecules, such as brevicomin and thiazole $(8,9)$, to recognize individual scent odours (10). MUPs of wild house mice exhibit a very high level of polymorphism: individual mice each express a combination of approximately 7-12 different MUPs (11). Male house mice were found to spend more time investigating scent marks of unrelated males or brothers that had different MUP type than scent marks of brothers with the same MUP type 
as themselves or their own scent marks (10). Thus, MUP type and MHC haplotype, derived from gene clusters on different chromosomes and inherited independently, may combine to provide a highly polymorphic individual signal that is unlikely to be shared even between siblings (10).

The importance of odours for mate recognition is not limited to nocturnal rodent species only. For example, in the ferret, a carnivore, both male and female ferrets strongly rely on volatile body odours to select an opposite-sex mating partner (12). In the domestic pig, a steroid compound, androstenone, has been identified in the male's saliva, that attracts oestrous sows and facilitates her display of receptive standing behaviour (13). This effect of androstenone on the female's behaviour is so striking that spraying the steroid onto a female pig is now routinely used to identify oestrous animals for the purpose of artificial insemination (14). Although the importance of odours to mate recognition in higher primates, including humans, appears to be relatively insignificant, Michael and Keverne (15) provided some evidence that odours may act as sex attractants in rhesus monkeys. Male monkeys were found to repeatedly press a lever to gain access to an ovariectomized female that was treated intravaginally with oestradiol but refused to do so to gain access to an ovariectomized female that received no steroid treatment. After their nasal passages had been plugged, these males still refused to press the lever for access to the latter female, even after she was treated intravaginally with oestradiol. However, after removal of the nasal plugs, males pressed the lever to access these females, suggesting that they were attracted to vaginal odours emitted in response to oestradiol. The finding that the males continued to press the bar to access for the original oestradiol-treated female even when their nasal passages were plugged suggests that other sensory cues such as visual and/or auditory cues were able to sustain their preference for this female.

The sex differences in sexual partner preference may actually reflect sex differences in how male and female mammals perceive odours that are important for mate recognition. This is supported by the finding that the ability to detect androstenone was sexually dimorphic in pigs (16). Similarly, Baum and Keverne (17) demonstrated sex differences in the ability to detect volatile urinary odours in mice. In the latter study, mice were tested several months after gonadectomy in the absence of any activational hormones, suggesting that the observed sex differences in olfactory sensitivity reflected perinatal, organizational effects of sex steroid hormones on olfactory function. Thus, increasing our understanding of how male and female mammals differentially perceive odours which are used to identify potential mates may be key to resolving the neural basis of heterosexual partner preference.

\section{Neural processing of odours}

Two olfactory systems have evolved in vertebrates which differ considerably in their peripheral anatomy and in their central neural projections. The first of these, the main olfactory system, is used to detect a wide variety of volatile odours derived from food prey and potential predators among many sources (18). Volatile odours are initially detected by olfactory sensory neurones in the main olfactory epithelium (MOE) whose axons project to specific clusters of glomeruli in the main olfactory bulb (MOB) resulting in a spatial map of activation $(19,20)$. The mitral and tufted relay neurones of the MOB in turn transmit signals onto the olfactory cortical structures, including the olfactory tubercle, anterior olfactory nucleus, piriform and entorhinal cortex (21-23). A second, or accessory olfactory system has evolved in vertebrates to detect and process a subset of nonvolatile odours that influence a variety of reproductive and aggressive behaviours in rodent species (24). Sensory neurones in the vomeronasal organ (VNO), a cigar-shaped organ located at the base of the nasal septum, detect nonvolatile odours which gain access to the VNO via a pumping mechanism (25). The olfactory information is then transmitted into the accessory olfactory bulb (AOB) (26) from where it will go into the limbic (amygdala), hypothalamic (bed nucleus of the stria terminalis; BNST and ventromedial hypothalamus) and preoptic area (POA) (27). The accessory olfactory system has many sexually dimorphic characteristics (both morphological and functional) at several levels along its projection pathway (28-30), whereas only a few reports exist on sex differences in the main olfactory system $(17,31)$.

\section{Relative roles of the main and accessory olfactory systems in mate recognition}

In rodent species, many effects of pheromones on reproductive and behavioural functions are mediated via the accessory olfactory inputs to the hypothalamus. For example, the increase in plasma luteinizing hormone ( $\mathrm{LH})$ and testosterone levels in male mice and hamsters exposed to female pheromones depends on the accessory olfactory system $(32,33)$. Furthermore, the occurrence of pregnancy block in recently mated female mice exposed to the odours of a novel male is mediated by the accessory olfactory system (34). However, whether the accessory olfactory system is equally important for mate recognition appears to be more controversial because evidence exists for a role of the main olfactory system in mate recognition and heterosexual partner preference. For example, female mice with zinc sulphate lesions of the MOE no longer preferred to approach soiled bedding from an intact as opposed to a castrated male, whereas VNO removal had no effect on their preference to approach soiled bedding (34). Similarly, removal of the VNO in male hamsters did not affect their ability to recognize a novel versus a familiar mate (35), and similar lesions in female hamsters had no effect on their ability to discriminate between several odours of other individuals using a habituation/ dishabituation paradigm (36). By contrast, evidence of a possible role of the VNO and thus the accessory olfactory system in mate recognition comes from two recent studies $(37,38)$ using mice that were homozygous for a null mutation of the transient receptor potential type 2 (TRP2) gene, a cation channel that apparently is expressed only in the VNO. Male TRP2 mutant mice mounted male and female mice indiscriminately and produced ultrasonic vocalizations in the presence of an oestrous female, a castrated male, or a castrated males swabbed with male urine (wild-type males vocalized only in the presence of an oestrous female). However, male mice carrying lesions in the VNO were able to discriminate between male and female conspecifics (39). Thus, which olfactory system is used for mate recognition in mice remains unclear. In humans, there has even been a long-standing dispute over whether there is a VNO at all, and thus pheromone communication among adults (4). The human VNO is vestigial, disappearing before birth (40). Furthermore, no AOB-like structure has been found in humans (41), thereby leaving little evidence for a functional accessory olfactory system in the adult. Nevertheless, pheromones have been demonstrated to influence mate 
choice as well as neuroendocrine function in other individuals (42, 43). Thus, pheromone communication in humans must depend solely on the main olfactory system.

This review will show that, in mice, the development of the neural mechanisms regulating the perception of odours important for mate recognition requires perinatal actions of oestradiol derived from neural aromatization of testosterone. Furthermore, it will be argued that mice, similar to ferrets and pigs, use primarily volatile odours that are detected and processed by the main olfactory system to identify and seek out opposite-sex mates.

\section{Sexual differentiation of mate recognition}

Numerous studies have shown that in mammals the differentiation of the male brain [i.e. masculinization (enhancement of maletypical sexual responses) and defeminization (suppression of female-typical sexual responses) of the neural substrates that control sexual behaviour in adulthood] depends on neural aromatization of testosterone to oestradiol during a critical perinatal period (44-47). In addition to these organizational effects, neural aromatization of testosterone has also been shown to be essential for activating male-typical sexual responses in adulthood, including coital behaviour, sexual motivation and partner preference (47-50). To date, very few studies have analysed the contribution of perinatal sex steroid hormones to the sexual differentiation of mate recognition and sexual partner preference in mice. This is surprising given the increased use of transgenic and gene-knockout mice in biomedical research. In one such study (51), male mice carrying a mutation in the oestrogen receptor alpha $(\mathrm{ER} \alpha \mathrm{KO})$, and which were then castrated in adulthood and treated with testosterone, failed to show a preference for an oestrous female when given a choice between an anaesthetized oestrous female and an anaesthetized intact male. The lack of olfactory investigation by $\mathrm{ER} \propto \mathrm{KO}$ males was not due to the inability of their accessory olfactory system to respond to female pheromones. Male ER $\alpha \mathrm{KO}$ and wild-type mice showed a similar induction of the immediate early gene, c-fos, which is commonly used as a marker for neuronal activity (52), in the AOB and in the medial amygdala, as well as in several hypothalamic regions receiving olfactory inputs after being exposed to soiled bedding from oestrous females (51). These results suggest that the detection and initial neural processing of female pheromones do not require oestrogen action, whereas the behavioural response to these female odours appears to require oestrogenic stimulation sometime in life. However, the ER $\alpha \mathrm{KO}$ mouse model cannot be used to distinguish between organizational and activational effects of oestradiol on brain function because the knockout of the ER is an irreversible manipulation that affects subjects from conception onwards. Furthermore, some effects of oestrogen may have been mediated by the second oestrogen receptor ER $\beta$. The recent introduction of the aromatase knockout mouse (ArKO) (53-55), which is deficient in aromatase activity due to a targeted mutation either in exons 1 and $2(54)$ or in exon $9(53,55)$ of the Cyp19 gene, has provided a new animal model to study the possible role of oestradiol in brain and behavioural sexual differentiation. Unlike ERKO mice, the ArKO mouse has functional oestrogen receptors. Thus, by administering oestradiol to adult ArKO mice, the consequences of the absence of oestradiol biosynthesis can be assessed earlier in life, thereby distinguishing between the organizational and activational effects of oestradiol on brain development and function. Following its introduction in 1998, most attention has been paid to analysing male coital behaviours in male ArKO mice (53-55), whereas studies on female ArKO mice have concentrated on their ovarian function (56) and body composition (57). Here, experiments are described that use the ArKO mouse model generated by Honda et al. (54) to study the contribution of oestradiol to the development of the neural mechanisms regulating mate recognition in both male and female mice (58-60).

\section{Oestrogenic control of mate recognition in male mice}

When provided with volatile olfactory cues in a Y-maze (Fig. 1), male ArKO mice, which were either gonadally intact or castrated and treated with testosterone in adulthood, failed to show a preference for the odours from an oestrous female whereas wild-type males clearly preferred to sniff oestrous odours (Fig. 2A) (58). However, the same ArKO males showed a preference for the oestrous female when given a choice between soiled bedding from oestrous females and that from intact males (Fig. 2B) (58). As stated in the introduction, the ability to detect nonvolatile odours that are contained in soiled bedding is thought to depend on the accessory olfactory pathway (61), suggesting that this pathway is functional in ArKO males. The behavioural differences when provided with volatile odours could have reflected differences in activation of olfactory investigation by oestradiol because no

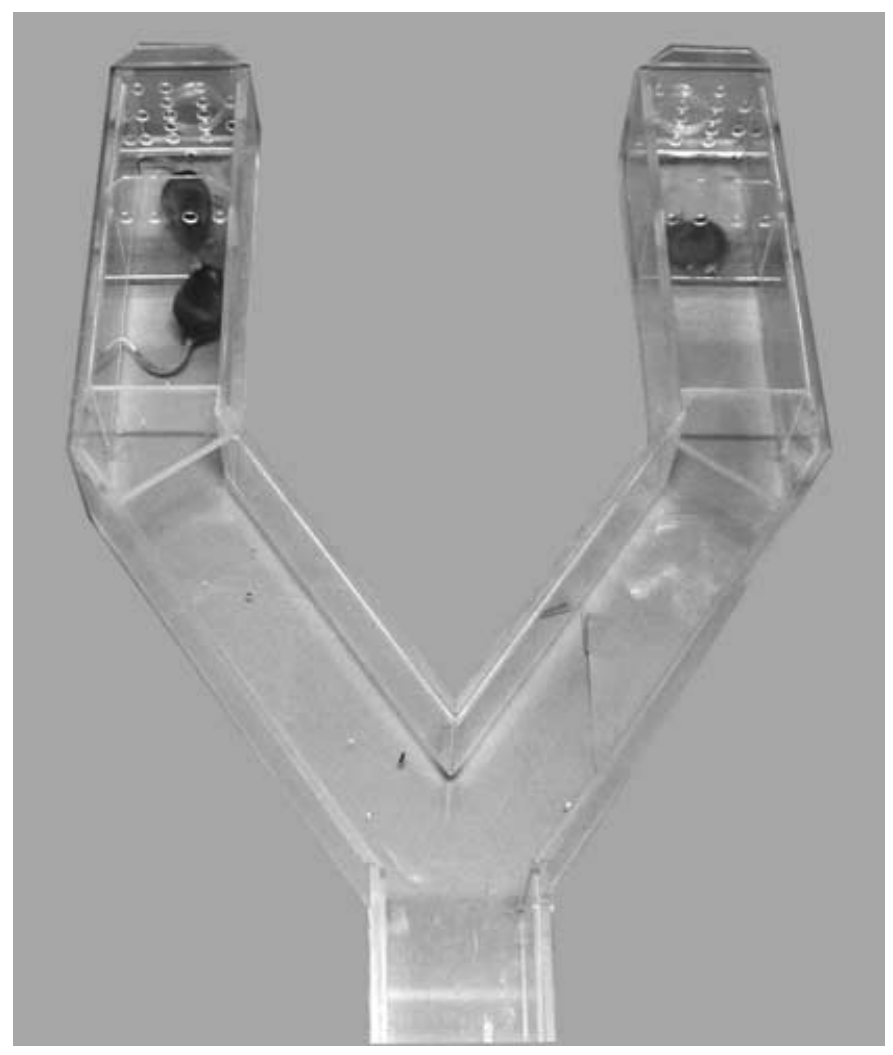

FIG. 1. Y-maze used to assess odour preferences in mice. When tested with volatile odours only, the doors to the goal boxes were opaque to prevent the subject from seeing the stimulus animal. Furthermore, stimulus animals were anaesthetized to prevent the subject from hearing the stimulus animal. When tested with nonvolatile odours, the doors to the goal boxes were removed and bowls of soiled bedding were placed in the goal boxes. 


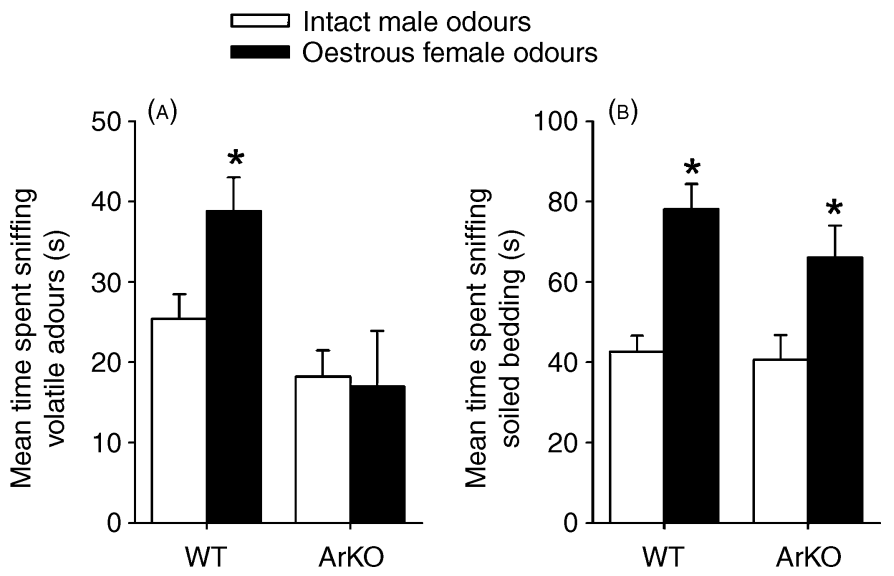

FIG. 2. The mean amount of time that gonadally intact male wild-type (WT) and aromatase knockout (ArKO) mice spent investigating volatile and nonvolatile odours when given a choice between intact male and oestrous female odour stimuli in a Y-maze. (A) Results when males were given a choice between volatile odour stimuli. (B) Results when males were given a choice between nonvolatile odour stimuli (soiled bedding). ${ }^{*} \mathrm{P}<0.05$ compared to male odours. Data are taken from a previous study (58).

oestradiol was circulating in gonadally intact or castrated, testosterone-treated ArKO males. Therefore, in order to distinguish between organizational and activational effects of oestradiol on olfactory investigation, ArKO males were tested for odour preferences after receiving treatment with oestradiol benzoate in adulthood (60). The deficits in olfactory investigation of volatile odours persisted after oestradiol treatment, suggesting that the development of the main olfactory system may depend on the presence of oestradiol at some point during development.

Taken together, the results obtained in male ArKO mice suggest that the main, as opposed to the accessory, olfactory system is affected by oestradiol-deprivation during development. This result is somewhat surprising because numerous studies have shown that the accessory olfactory system is sexually differentiated under the influence of oestrogens $(28,29)$. However, it is possible that volatile body odours are also detected by the accessory olfactory system because it has been shown that sensory neurones in the VNO may occasionally respond to volatile molecules in vitro (62). However, it should be noted that no evidence exists of this actually occurring in vivo.

\section{Oestrogenic control of mate recognition in female mice}

By contrast to male differentiation, a possible role of oestradiol in the differentiation of female-typical aspects of neuroendocrine and behavioural function has received much less attention. It is generally assumed that the sexual differentiation of the brain is biased into a female direction (i.e. in the absence of testosterone and/or oestradiol, female-typical neural and behavioural traits develop). This concept is based on early studies showing that female guinea-pigs treated in utero with testosterone propionate showed elevated levels of male-typical mounting behaviour in adulthood, whereas male rats castrated on the day of birth showed female-typical lordosis behaviours when treated with ovarian hormones in adulthood (63-65). However, the possible importance of sex steroids in the differentiation of the female brain was suggested by Toran-Allerand (66) who found that oestradiol promoted neurite outgrowth from foetal hypothalamic explants of both sexes. This hypothesis was further supported by several behavioural studies showing that perinatal exposure to low levels of oestrogens facilitated the capacity to display female sexual behaviour in adulthood (67-69). However, they did not provide unequivocal evidence that oestradiol is indispensable for the development of female sexual behaviour in female mammals. The hypothesis subsequently languished due to the lack of a suitable animal model to test the possible contribution of oestrogen to the development of the female brain.

The recent introduction of the ArKO mouse provided an ideal opportunity to readdress the hypothesis that the normal femaletypical differentiation of brain and behaviour requires perinatal exposure to oestradiol (59). When treated with testosterone, ovariectomized ArKO females spent significantly less time than wild-type females investigating both volatile and nonvolatile odours from male and oestrous female conspecifics in a Y-maze. The deficits in olfactory investigation of volatile odours by ArKO females persisted after oestradiol treatment in adulthood, suggesting that the normal, female-typical differentiation of the capacity of the main olfactory system to respond to volatile odours may depend on the presence of oestrogenic stimulation at some earlier point during development (Fig. 3A) (59). By contrast, oestradioltreated ArKO females spent as much time as wild-type females investigating soiled bedding of gonadally intact males and oestrous females (Fig. 3B) (59). These findings suggest that the accessory olfactory system is functional in ArKO females, as was previously found in ArKO males (58). This conclusion was corroborated by the results of Lau et al. (70). In their experiment, the ability of odours from soiled male bedding to induce neuronal Fos in sensory neurones located in both the apical and basal zones of the VNO and in two segments of the accessory olfactory pathway, the anterior nucleus of the medial amygdala and the BNST, was significantly reduced in adult, ovariectomized, oestradiol-treated ArKO females. However, a robust odour-induced activation of Fos was seen in other segments of the accessory olfactory pathway of ArKO females, including the AOB granular

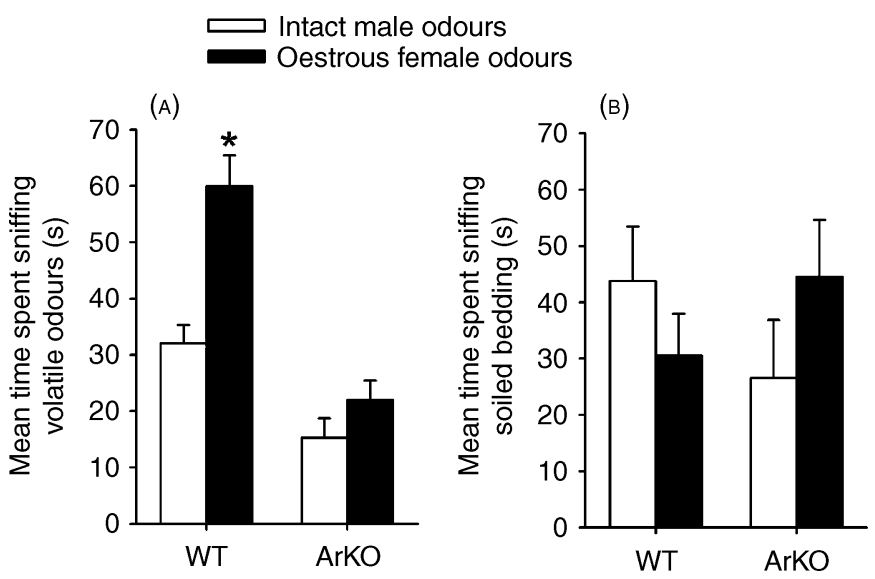

FIG. 3. The mean amount of time that female wild-type (WT) and aromatase knockout (ArKO) mice spent investigating volatile and nonvolatile odours when given a choice between intact male and oestrous female odour stimuli in a Y-maze. (A) Results when females were given a choice between volatile odour stimuli. (B) Results when females were given a choice between nonvolatile odour stimuli (soiled bedding). All females were ovariectomized in adulthood and subsequently treated with oestradiol. ${ }^{*} \mathrm{P}<0.05$ compared to male odours. Data are taken from a previous study (59). 
cell layer, the posterior-dorsal medial amygdala, and the medial POA. These results suggest that, despite reduced responsiveness in several component structures, the accessory olfactory pathway to the hypothalamus remains functional in ArKO females.

\section{Conclusions and future directions}

The introduction of the ArKO mouse has provided a new opportunity to analyse the role of oestradiol in the development of the neuroendocrine mechanisms controlling mate recognition. The results obtained in male ArKO mice have thus far confirmed the results from previous studies that used perinatal administration of aromatase blocking drugs (47), which suggest that oestradiol derived from neural aromatization of testosterone promotes male-typical differentiation of the neural systems regulating mate recognition in male mammals. By contrast, the results obtained in female ArKO mice have provided new evidence for a role of oestradiol in female-typical differentiation of the neural mechanisms regulating mate recognition in female mammals.

The neural mechanisms that control mate recognition appear to include the main olfactory system. The low levels of olfactory investigation observed in ArKO mice of both sexes compared with wild-type mice when presented with volatile body odours from an intact male and an oestrous female in a Y-maze (58-60) could reflect deficits in the ability of the main olfactory system to detect and/or discriminate volatile urinary odours derived from male as opposed to female conspecifics. Using habituation/dishabituation tests, Baum and Keverne (17) found that the capacity to detect and investigate decreasing concentrations of volatile urinary odours is sexually differentiated in mice. Females were better able than males to detect higher dilutions of volatile urine odours derived from either males or oestrous females. The gonadectomized mice were tested without any activational hormones circulating, implying that the observed sex differences in olfactory sensitivity reflected organizational effects of sex hormones on the main olfactory system. Thus, it is possible that main olfactory function is not 'masculinized' in male ArKO mice and not 'feminized' in female ArKO mice due to the absence of oestradiol during development and, as a consequence, they are deficient in their ability to detect low concentrations of volatile urinary odours. Additional studies on the functional and anatomical features of the main olfactory system in ArKO vs wild-type mice are needed in order to establish more conclusively a developmental role for oestradiol in the main olfactory system and thus in mate recognition.

The accessory olfactory system appeared to be minimally affected in ArKO mice of both sexes. Male and female ArKO mice spent as much time as wild-type animals investigating soiled bedding of gonadally intact males and oestrous females, although adult treatment with oestradiol to ArKO females appeared to be required to stimulate olfactory investigation of soiled bedding ( 58 , 59). These findings suggest that oestradiol is not a prerequisite for the development of the accessory olfactory system. This is surprising with respect to the strong sexually dimorphic nature of this pathway (28-30). For example, using the expression of $c$ fos, the ability of the accessory olfactory system to respond to male soiled bedding has been found to be sexually differentiated by perinatal oestrogens in the rat (29). Male rats treated neonatally with the aromatase inhibitor, ATD, and then castrated in adulthood and treated with oestradiol, showed female-like Fos responses to male soiled bedding in the more central areas of the accessory olfactory pathway (i.e. the BNST and medial POA). However, neonatally ATD-treated male rats preferred to investigate soiled bedding from oestrous females over that from intact males (71), implying that odour preferences cannot be predicted by neural Fos responses in the accessory olfactory system. Additional studies on the functional and anatomical features of the accessory olfactory system in ArKO versus wild-type mice are needed in order to establish more conclusively whether oestradiol contributes to the development of the accessory olfactory system. For example, experiments should be conducted to determine whether ArKO males and females are capable of showing reflexive LH surges when exposed to pheromones of opposite-sex conspecifics in order to establish whether the accessory olfactory pathway is functional in these mice.

Finally, results obtained in ArKO mice suggest that mice, similar to ferrets and pigs, use volatile body odours which are detected by the main olfactory system to identify potential mates. This finding challenges the general belief that favours a role for the accessory olfactory system in reproductive behaviours, including mate recognition. This belief was recently further fed by results obtained in male TRP 2 mutant mice $(37,38)$ because these mice appeared to be gender blind. However, many questions remain unanswered about olfactory function of these male TRP2 mutant mice, in particular, because male mice carrying lesions in the VNO were able to discriminate between male and female conspecifics (39). Furthermore, there are actually strong indications for a role of the main olfactory system in mate recognition $(20,34-36)$. It is worth noting that sex differences may exist in the role of the VNO in discrimination of individual odours (72). Lesions of the VNO resulted in elimination of some individually distinctive (but not all) odours in male hamsters whereas, in female hamsters, such lesions had no effect on olfactory discrimination. In this respect, it would be interesting to determine whether female TRP2 mutant mice show similar deficits in gender discrimination as male TRP2 mutant mice.

In conclusion, sex differences in sexual partner preference may reflect sex differences in the perception of volatile body odours which are important for mate recognition by the main olfactory system. Furthermore, oestrogens contribute to the development of the main olfactory system and, in this way, may induce sex differences in mate recognition and, subsequently, sexual partner preference.

\section{Acknowledgements}

I would like to thank Dr Michael Baum for his critical reading of this manuscript.

Accepted 10 March 2003

\section{References}

1 Brown RE. Mammalian social odors: a critical review. Adv Study Behav 1979; 10: 103-162.

2 Vandenbergh JG. Pheromones and mammalian reproduction. In: Knobil B, Neill JD, eds. Physiology of Reproduction, 2nd edn. New York: Raven Press, 1994: 343-359.

3 Karlson P, Luscher M. 'Pheromones': a new term for a class of biologically active substances. Nature 1959; 183: 55-56.

4 Meredith M. Human vomeronasal organ function. A critical review of best and worst cases. Chem Senses 2001; 26: 433-445.

5 Yamazaki K, Boyse EA, Mike V, Thaler HT, Mathieson BJ, Abbott J, Boyse J, Zayas ZA, Thomas L. Control of mating preferences in mice by 
genes in the major histocompatibility complex. J Exp Med 1976; 144: 1324-1335.

6 Singh PB, Brown RE, Roser B. MHC antigens in urine as olfactory recognition cues. Nature 1987; 327: 161-164.

7 Potts WK, Manning CJ, Wakeland EK. Mating patterns in seminatural populations of mice influenced by MHC genotype. Nature 1991; 352: 619-621.

8 Bocskei Z, Findlay JB, North AC, Phillips SE, Somers WS, Wright CE, Lionetti C, Tirindelli R, Cavaggioni A. Crystallization of and preliminary $\mathrm{X}$-ray data for the mouse major urinary protein and rat alpha-2u globulin. J Mol Biol 1991; 218: 699-701.

9 Bacchini A, Gaetani E, Cavaggioni A. Pheromone binding proteins of the mouse, mus musculus. Experientia 1992; 48: 419-421.

10 Hurst JL, Payne CE, Nevison CM, Marie AD, Humphries RE, Robertson DHL, Cavaggioni A, Beynon RJ. Individual recognition in mice mediated by major urinary proteins. Nature 2001; 414: 631-634.

11 Robertson DH, Cox KA, Gaskell SJ, Evershed RP, Beynon RJ. Molecular heterogeneity in the major urinary proteins of the house mouse, mus musculus. J Biochem 1996; 316: 265-272.

12 Kelliher KR, Baum MJ. Nares occlusion eliminates heterosexual partner selection without disrupting coitus in ferrets of both sexes. $J$ Neurosci 2001; 21: 5832-5840.

13 Signoret JP. Reproductive behavior of pigs. J Reprod Fert Suppl 1970; 11: 105.

14 Reed HD, Melrose DR, Patterson RLS. Androgen steroids as an aid to the detection of oestrus in pig artificial insemination. Br Vet $J$ 1974; 130: 61-67.

15 Michael RP, Keverne EB. Primate sex pheromones of vaginal origin. Nature 1968; 225: 84-85.

16 Dorries KM, Adkins-Regan E, Halpern BP. Olfactory sensitivity to the pheromone, androstenone, is sexually dimorphic in the pig. Physiol Behav 1995; 57: 255-259.

17 Baum MJ, Keverne EB. Sex difference in attraction thresholds for volatile odors from male and female mouse urine. Horm Behav 2002; 41: $213-219$.

18 Firestein S. How the olfactory system makes sense of scents. Nature Rev 2001; 413: 211-218.

19 Wilson DA, Leon M. Spatial patterns of olfactory bulb single-unit responses to learned olfactory cues in young rats. J Neurophysiol 1988; 59: $1770-1782$.

20 Schaeffer ML, Young DA, Restrepo D. Olfactory fingerprints for major histocompatibility complex-determined body odors. J Neurosci 2001; 21: 2481-2487.

21 Scott JW. The olfactory bulb and central pathways. Experientia 1986; 42: 223-232.

22 Price JL. In: Finger TE, Sliver WL, eds. Neurobiology of Taste and Smell. New York: John Wiley, 1987: 179-203.

23 Shipley MT, Ennis M. Functional organization of the olfactory system. J Neurobiol 1996; 30: 123-176.

24 Keverne EB. The vomeronasal organ. Science 1999; 286: 716-720.

25 Meredith M, O'Connell RJ. Efferent control of stimulus access to the hamster vomeronasal organ. J Physiol 1979; 286: 301-316.

26 Wysocki CJ, Wellington JL, Beauchamp GK. Access of urinary nonvolatile to the mammalian vomeronasal organ. Science 1980; 207: 781-783.

27 Scalia F, Winans SS. The differential projections of the olfactory bulb and accessory olfactory bulb in mammals. J Comp Neurol 1975; 161: $31-55$.

28 Guillamon A, Segovia S. Sex differences in the vomeronasal system. Brain Res Bull 1997; 44: 377-382.

29 Bakker J, Baum MJ, Slob AK. Neonatal inhibition of brain estrogen synthesis alters adult neural Fos responses to mating and pheromonal stimulation in the male rat. Neuroscience 1996; 74: 251-260.

30 Bressler SC, Baum MJ. Sex comparison of neuronal Fos immunoreactivity in the rat vomeronasal projection circuit after chemosensory stimulation. Neuroscience 1996; 71: 1063-1072.

31 Weruaga E, Brinon JG, Poteros A, Arevalo R, Aijon J, Alonso JR. A sexually dimorphic group of atypical glomeruli in the mouse olfactory bulb. Chem Senses 2001; 26: 7-15.

32 Coquelin A, Clancy AN, Macrides F, Noble EP, Gorski RA. Pheromonally induced release of luteinizing hormone in male mice: involvement of the vomeronasal organ. J Neurosci 1984; 4: 2230-2236.

33 Pfeiffer CA, Johnston RE. Hormonal and behavioral responses of male hamsters to females and female odors: roles of olfaction, the vomeronasal system, and sexual experience. Physiol Behav 1994; 55: 129-138.
34 Lloyd-Thomas A, Keverne EB. Role of the main and accessory olfactory system in the block to pregnancy in mice. Neuroscience 1982; 7: 907913.

35 Johnston RE, Rasmussen K. Individual recognition of female hamsters by males: role of chemical cues and of the olfactory and vomeronasal systems. Physiol Behav 1984; 33: 95-104.

36 Petrulis A, Peng M, Johnston RE. Effects of vomeronasal organ removal on individual odor discrimination, sex-odor preference, and scent marking in female hamsters. Physiol Behav 1999; 66: 73-83.

37 Stowers L, Holy TE, Meister M, Dulac C, Koentges G. Loss of sex discrimination and male-male aggression in mice deficient for TRP2. Science 2002; 295: 1493-1500.

38 Leypold BGYuCR, Leinders-Zufall T, Kim MM, Zufall F, Axel R. Altered sexual and social behaviors in trp2 mutant mice. Proc Natl Acad Sci USA 2002; 99: 6376-6381.

39 Keverne EB. Mammalian pheromones: from genes to behaviour. Curr Biol 2002; 12: R807-R809.

40 Trotier D, Eloit C, Wassef M, Talmain G, Bensimon JL, Doving KB, Ferrand J. The vomeronasal cavity in adult humans. Chem Senses 2000; 25: 369-380.

41 Meisami E, Bhatnagar KP. Structure and diversity in mammalian accessory olfactory bulb. Res Tech 1998; 43: 476-499.

42 Wedekind C, Seebeck T, Bettens F, Paepke AJ. MHC-dependent mate preferences in humans. Proc $R$ Soc Lond B Biol Sci 1995; 260: 245-249.

43 Stern K, McClintock MK. Regulation of ovulation by human pheromones. Nature 1998; 392: 177-179.

44 Naftolin F, Ryan KJ, Davies IJ, Reddy VV, Flores F, Petro Z, Kuhn M, White RJ, Takoaka Y, Wolin L. The formation of estrogens by central neuroendocrine tissues. Rec Prog Horm Res 1975; 31: 295-315.

45 Baum MJ. Differentiation of coital behavior in mammals: a comparative analysis. Neurosci Biobehav Rev 1979; 3: 265-284.

46 MacLusky NJ, Naftolin F. Sexual differentiation of the central nervous system. Science 1981; 211: 1294-1303.

47 Bakker J, Brand T, van Ophemert J, Slob AK. Hormonal regulation of adult partner preference behavior in neonatally ATD-treated male rats. Behav Neurosci 1993; 107: 480-487.

48 Davidson JM. Effects of estrogen on the sexual behavior of male rats. Endocrinology 1969; 84: 1365-1372.

49 Baum MJ, Carroll RS, Cherry JA, Tobet SA. Steroidal control of behavioral, neuroendocrine, and brain sexual differentiation: studies in a carnivore, the ferret. $J$ Neuroendocrinol 1990; 2: 401-418.

50 Balthazart J, Reid J, Absil P, Foidart A, Ball GF. Appetitive as well as consummatory aspects of male sexual behavior in quail are activated by androgens and estrogens. Behav Neurosci 1995; 109: 485-501.

51 Wersinger SR, Rissman EF. Oestrogen receptor $\alpha$ is essential for female-directed chemo-investigatory behaviour but is not required for the pheromone-induced luteinizing hormone surge in male mice. $J$ Neuroendocrinol 2000; 12: 103-110.

52 Morgan JI, Cohen DR, Hempstead JL, Curran T. Mapping patterns of c-fos expression in the central nervous system after seizure. Science 1987; 237: 192-197.

53 Fisher CR, Graves KH, Parlow AF, Simpson ER. Characterization of mice deficient in aromatase (ArKO) because of targeted disruption of the Cyp19 gene. Proc Natl Acad Sci USA 1998; 95: 6965-6970.

54 Honda S, Harada N, Ito S, Takagi Y, Maeda S. Disruption of sexual behavior in male aromatase-deficient mice lacking exons 1 and 2 of the Cyp19 gene. Biochem Biophys Res Comm 1998; 252: 445-449.

55 Toda K, Okada T, Takeda K, Akira S, Saibara T, Shiraishi M, Onishi S, Shizuta Y. Oestrogen at the neonatal stage is critical for the reproductive ability of male mice as revealed by supplementation with $17 \mathrm{~b}$-oestradiol to aromatase gene (Cyp19) knockout mice. J Endocrinol 2001; 168: 455-463.

56 Britt KL, Drummond AE, Cox VA, Dyson M, Wreford NG, Jones ME, Simpson ER, Findlay JK. An age-related ovarian phenotype in mice with targeted disruption of the Cyp19 (aromatase) gene. Endocrinology 2000; 141: 2614-2623.

57 Jones ME, Thorburn AW, Britt KL, Hewitt KN, Wreford NG, Proietto J, $\mathrm{Oz}$ OK, Leury BJ, Robertson KM, Yao S, Simpson ER. Aromatasedeficient (ArKO) mice have a phenotype of increased adiposity. Proc Natl Acad Sci USA 2000; 97: 12735-12740.

58 Bakker J, Honda S, Harada N, Balthazart J. Sexual partner preference requires a functional aromatase (Cyp19) gene in male mice. Horm Behav 2002; 42: 158-171.

59 Bakker J, Honda S, Harada N, Balthazart J. The aromatase-knockout mouse provides new evidence that estradiol is required during develop- 
ment in the female for the expression of sociosexual behaviors in adulthood. J Neurosci 2002; 22: 9104-9112.

60 Bakker J, Honda S, Harada N, Balthazart J. Estradiol is required during development for the expression of odor preferences in male mice. Soc Neurosc Abstract 2002; 383: 3.

61 O'Connell RJ, Meredith M. Effects of volatile and nonvolatile chemical signals on male sex behaviors mediated by the main and accessory olfactory systems. Behav Neurosci 1984; 98: 1083-1093.

62 Sam M, Vora S, Malnic B, Ma W, Novotny MV, Buck LB. Neuropharmacology. Odorants may arouse instinctive behaviours. Nature 2001; 412: 142.

63 Phoenix CH, Goy RW, Gerall AA, Young WC. Organizational action of prenatally administered testosterone propionate on the tissues mediating mating behavior in the female guinea pig. Endocrinology 1959; 65: 369-382.

64 Grady KL, Phoenix CH, Young WC. Role of the developing rat testis in differentiation of the neural tissues mediating mating behavior. J Comp Physiol Psychol 1965; 59: 176-182.

65 Feder HH, Whalen RE. Feminine behavior in neonatally castrated and estrogen-treated male rats. Science 1965; 147: 306-307.

66 Toran-Allerand CD. Sex steroids and the development of the newborn mouse hypothalamus and preoptic area in vivo: implications for sexual differentiation. Brain Res 1976; 106: 407-412.
67 Gerall AA, Dunlap JL, Hendricks SE. Effect of ovarian secretions on female behavioral potentiality in the rat. J Comp Physiol Psychol 1973; 82: 449-465.

68 Döhler KD, Hancke JL, Srivastava SS, Hofman C, Shrine JE, Gorski RA. Participation of estrogens in female sexual differentiation of the brain: neuroanatomical, neuroendocrine, and behavioral evidence. In: De Vries GJ, De Bruin JPC, Uylings HBM, Corner MA, eds. Progress in Brain Research, vol. 61. Sex Differences in the Brain: the Relation Between Structure and Function. Amsterdam: Elsevier, 1984: 99-117.

69 Baum MJ, Tobet SA. Effect of prenatal exposure to aromatase inhibitor, testosterone, or antiandrogen on the development of feminine sexual behavior in ferrets of both sexes. Physiol Behav 1986; 37: $111-118$.

70 Lau YE, Cherry JA, Baum MJ, Mani SK. Induction of Fos in the accessory olfactory system by male odors persists in female mice with a null mutation of the aromatase (Cyp19) gene. Brain Res Bull 2003; in press.

71 Bakker J, van Ophemert J, Slob AK. Sexual differentiation of odor and partner preference in the rat. Physiol Behav 1996; 60: 489-494.

72 Johnston RE, Peng M. The vomeronasal organ is involved in discrimination of individual odors by males but not by females in golden hamsters. Physiol Behav 2000; 70: 537-549. 